\title{
Sustainable Supply Chain Management in the Book Publishing Sector
}

\author{
Manuel Díaz-Madroñero \\ Josefa Mula \\ Raúl Poler \\ Escuela Politécnica Superior de Alcoy Plaza Ferrándiz y Carbonell, \\ Universitat Politècnica de València (UPV), Alcoy, Alicante, Spain
}

\begin{abstract}
In recent years, the term sustainability has been considered by the academic community in the management, logistics and supply management areas. The emerging concept of sustainable supply chain management tries to balance economic long-term benefit of the members of the supply chain, as well as the environmental and social decisions, in order to satisfy the interests of the individual members of a supply chain and their stakeholders. The aim of this paper is to analyze the current status of sustainable supply chain management and its application to the Book Publishing sector. For this purpose, a review process of selected papers applied to the Book Publishing sector is carried out, from which the main conclusion is that there are no references which consider in an integrated way all partners in the supply chain Book Publishing industry (e.g. publishers, printers, distributors, retailers).

Keywords: Supply chain management, Sustainability, Sustainable supply chain management, Social responsibility, Economic sustainability, Book Publishing sector.
\end{abstract}

\section{Introduction}

The supply chain management (SCM) encompasses the planning and management of all activities involved in sourcing and procurement, conversion, and all logistics management activities (Council of Supply Chain Management Professionals, 2012), for the purposes of improving the long term performance of the individual companies and the supply chain (SC) as a whole (Mentzer et al., 2001). The emergence of global supply chains during the last decades has been due to the economic benefits associated with shifting production to countries with lower labor costs and less strict regulations. This has involved a significant increase in long distance transport and logistics activities associated. However, despite being economically feasible, these supply chains are not sustainable from the point of view of its negative impact in relation to environmental and social aspects. For example, relocation of manufacturing activities in countries far from the final customers can increase the carbon footprint associated with production and delivery of products to end customers as well as destruction of employment in countries of origin. 
Sustainable Supply Chain Management (SSCM) have been emerged in recent years as a new management approach which tries to embed economic, environmental as well as societal decisions in supply chains (Wu and Pagell, 2011) and offers the opportunity to differentiate from other companies by being equitable in the fair utilization of natural resources. Some examples of SSCM case studies in different sectors can be found in the literature such as Textile (Seuring and Müller, 2008), Chemical (Foerstl et al., 2010) or Automotive (Olugu et al., 2010), but there are not available studies focused on Book Publishing sector. The aim of this paper is to analyze the current status of SSCM and its application to the Book Publishing sector.

The rest of the paper is arranged as follows: the next section introduces the review methodology. Section 3 offers a description review about SSCM issues. Section 4 presents a brief literature review about SSCM initiatives in the Book Publishing sector. Section 5 proposes some initiatives related to sustainability in Book Publishing sector. Finally, the last section provides conclusions and directions for further research.

\section{Review Methodology}

The search process was carried out with scientific-technical bibliographic databases such as ISI Web of Knowledge and Google Scholar. The following search criteria were applied: sustainable supply chain management, green supply chain management, corporate social responsibility, sustainability and environmental issues in book publishing sector. Furthermore, the bibliographic references of the articles studied have served as a continuous search reference. At the conclusion of this period, a collection of 70 references was collected with a time frame covering 1971 to 2012 .

Two groups may be distinguished in these reviewed works; on the one hand, articles in which different supply chain management concepts and sustainable practices are proposed in general terms while, on the other hand, articles that propose different sustainable supply chain management solutions for the Book Publishing sector. This last group consists of 14 references which references were obtained from journals (7 references), conferences ( 3 references) and professional publications from publishers associations (4 references).

\section{Sustainable Supply Chain Management}

Responsible concepts such as sustainability or sustainable development first appeared in 70s and were widely used by practitioners in environmental and development areas. In these years, sustainability was employed to de 'scribe an economy in equilibrium with basic ecological support systems (Stivers, 1976). On the other hand, the most accepted and widely used definition of sustainable development was proposed by the Brundtland Commission which stated this concept as "[...] a development that meets the needs of the present without compromising the ability of future generations to meet their own needs." (World Commission on Environment and Development, 1987, p. 43).

Apart from the several definitions of sustainability, the model proposed by Elkington (1998, 2004), called the Triple Bottom Line (TBL), has been taken as a reference to materialize the sustainable concepts in management environments. From a microeconomic perspective, this model simultaneously considers economic, 
environmental and social goals, at whose intersection there may be activities that not only positively affect the natural environment and society, but which also result in long-term economic benefits and competitive advantage for the companies.

In recent years, the term sustainability and the integration of economic, environmental and social issues have begun to appear in the literature related to business management, operations management, logistics and supply chains. Srivastava (2007) presents a comprehensive and integrated view of the published literature on all the aspects related to Green Supply Chain Management (GrSCM), by focusing on ecological and reverse logistics issues such as green design (Zhang et al., 1997); green purchasing (Zhu and Geng, 2001); repairable inventory (Guide et al., 1999, 1997b); production planning and control for remanufacturing (Bras and McIntosh, 1999; Guide et al., 1997a, b); issues in green manufacturing and product recovery (Guide et al., 1996; Gungor and Gupta, 1999); reverse logistics (Carter and Ellram, 1998; Fleischmann et al., 1997); logistics network design (Fleischmann et al., 2001, 2000; Jayaraman et al., 2003) and industrial ecology and industrial ecosystems (Bey, 2001; Hui et al., 2001; Sarkis and Cordeiro, 2001; Zhu and Sarkis, 2004).

On the other hand, Carter and Rogers (2008) and Seuring and Müller (2008) present complete literature reviews about the sustainability concept in the management and logistics areas and SSCM, respectively. According to Carter and Rogers (2008), in the management literature, most of the existing conceptualizations of organizational sustainability have focused on ecological sustainability, with an implicit consideration of social and economic responsibilities (Jennings and Zandbergen, 1995; Shrivastava, 1995; Starik and Rands, 1995). However, in operations management literature, social aspects of sustainability have been often addressed explicitly and added to the ecological perspective (Daily and Huang, 2001; Hill, 2001; Sarkis, 2001). On the other hand, within the field of supply chain management, researchers have examined several stand-alone topics of environmental and social issues. Svensson (2007) identifies several sustainable business practices in supply chains such as corporate social responsibility (Dyllick and Hockerts, 2002); sustainable supply network management (Young and KielkiewiczYoung, 2001); supply chain environmental management (Lippmann, 1999); green purchasing strategies (Min and Galle, 1997); environmental purchasing (Zsidisin and Siferd, 2001); environmental marketing (Sheth and Parvatiyar, 1995); environmental marketing management (Peattie, 1995) and environmental product differentiation (Reinhardt, 1999); reverse logistics (Zikmund and Stanton, 1971); sustainability labelling schemes (De Boer, 2003); environmental management (Hoffman, 2000) and life-cycle assessment (Welford, 1999) and ISO 14000-certifications (International Organisation for Standardisation, 2012).

Based on previous definitions of SCM (Lambert, 2008; Mentzer et al., 2001) and the Triple Bottom Line model (Elkington, 1998, 2004), Carter and Rogers (2008) presents a framework for SSCM and define it as the strategic, transparent integration and achievement of an organization's social, environmental and economic goals in the systemic coordination of key inter-organizational business processes for improving the long-term economic performance of the individual company and its supply chains. However, Seuring and Müller (2008) conclude that research is still dominated by green and environmental issues, while social issues and also the integration of the three dimensions of SSCM are still rare. 


\section{Sustainable Supply Chain Management in the Book Publishing sector}

The importance of the Book Publishing sector lies in being the first cultural industry in Europe with an annual sales revenue of book publishers of approximately 23 billion EUR according to a survey conducted by the Federation of European Publishers for the year 2009. A total of about 515.000 new titles were issued by publishers in 2009. The largest markets in terms of publishers' turnover in 2009 were Germany, followed by the UK, France, Spain and Italy. European publishers held a total of close to 6,5 million different titles in stock, the countries reporting the largest availability being the UK (2,4 million), Germany (around 1,2 million), Italy (almost 700.000), France (over 600.000) and Spain (over 400.000).

The Book Publishing Supply Chain includes the publishers, the printers and paper manufacturers, the distributors and logistics suppliers and the bookstores. The structure and logistics flows of a current Book Publishing Supply Chain are showed in Figure 1.The emergence of new publishing formats, both printed and electronic, has changed the traditional structure of the sector and the relations among its members, creating a complex structure involving a large number of possible scenarios depending on the production amounts, the supply of raw materials, the geographic location among members, or return rates from bookstores. The characteristics of these different scenarios determine the sustainability of books during their life cycle including the forward and reverse logistics.

There exist different initiatives for the improvement of the Book Publishing Supply Chain. They are focused on improving the efficiency of the information flows by means of encoding (Federation of National Associations of Distributors of Editions in Spain, 2012), communication procedures (Spanish Association of Publishers Guilds, 2012) and databases (Spanish Confederation of Booksellers' Associations, 2012), however, to the best of our knowledge, there is no research work in the SSCM literature related to the Book Publishing sector. Only, there are some studies dealing with individual sustainable practices or environmental aspects. For instance, Green Press Initiative (2008) discusses the impacts that producing books and newspapers have on global climate change. The report also identifies the greatest sources of greenhouse gas emissions associated with publishing, and provides the steps that will yield the greatest reductions in climate impacts. Because of increasing concern about

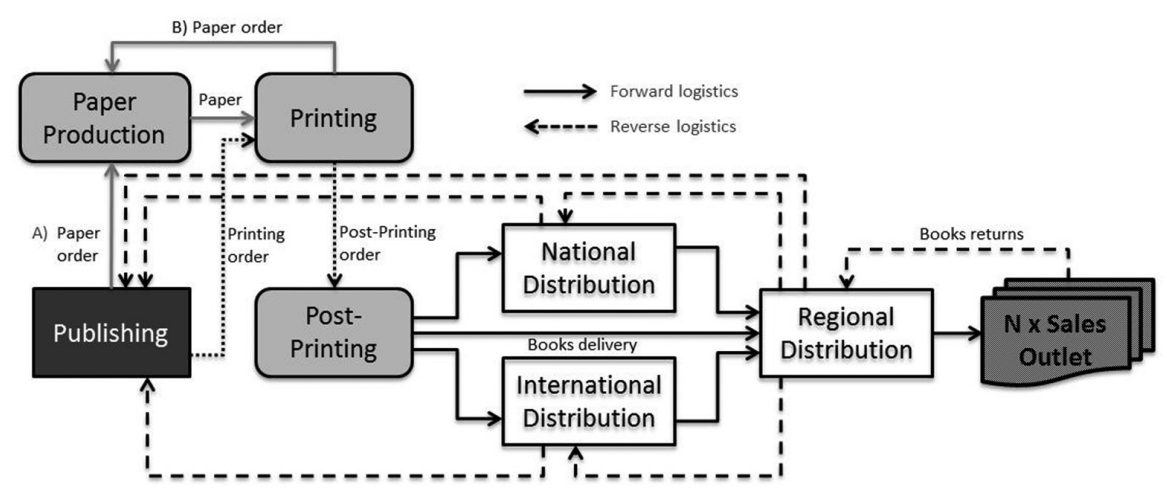

Figure 1. Book Publishing Supply Chain. 
global climate change and carbon emissions as a causal factor (Rotz et al., 2010), the term "carbon footprint" has become popular over the last few years. Carbon footprint is a measure based on life cycle thinking and the Life Cycle Assessment (LCA) methodology and it is referred to the quantity of GreenHouse Gases (GHGs) produced during a product's life cycle (Pihkola et al., 2010). In this sense, Chowdhury (2010) studies the carbon footprint of the knowledge industry, from creation to distribution and use of knowledge, and provides comparative figures for digital distribution and access by conducting an extensive literature search to produce data relating to the $\mathrm{CO}_{2}$ emissions from various industries and activities such as book and journal production, photocopying activities, information technology and the internet. Moreover, Matthews et al. (2008) develop equations for calculating carbon footprint in the United States Book Publishing sector.

Matthews et al. (2002), Williams and Tagami (2002) and Xu et al. (2008, 2009) assess the environmental impacts and energy consumptions associated with the distribution of books via e-commerce and conventional retail in USA and Japan. Matthews et al. (2002) present two LCAs of online versus traditional retailing, one for the case of the USA and a subsequent one for Japan. In terms of methodology, the former uses an extended version of Economic Input-Output Life Cycle Assessment (EIO-LCA) (Carnegie Mellon University Green Design Initiative, 2001), which includes total supply chain effects, while the latter is based on a traditional LCA. Both studies consider the energy consumed in distribution, packaging and personal transport, but beyond these basic factors, the focus issues are different. The US study has a larger system boundary, and highlights switching of truck-rail-air modes and inventory reductions associated with online retailing, while the Japan work focuses on the effect of population density, mode of consumer transport, and changes in residential energy consumption. Williams and Tagami (2002) significantly improve the estimation of energy used in sales and distribution via e-commerce and traditional retail by taking into account the consumer travel to and from bookstore (for the traditional model), the relative efficiency of bulk shipping versus courier services, relative energy consumption induced at home for an on-line purchase versus that of retail outlets, including the lifecycle energy of personal computer use at home. Xu et al. $(2008,2009)$ explore the dynamics of an e-commerce market and the associated environmental impacts from a bottom-up perspective using an agent-based model. A conceptual meta-theory from psychology is adopted to form the behavioural rules of artificial consumers choosing different methods of buying a book, including conventional bookstores, e-commerce, and a proposed self-pick-up option.

Logistics is an essential process that seeks to optimize flows of materials and products in supply chains and configurations of supply networks (Sadegheih et al., 2010). Kim et al. (2008, 2009) present a sustainable networked delivery (SND) system applied to a case study of book distribution sector. The SND system is a combination of e-commerce and centralized pickup point (PP), with the PP being a location that the consumer will already be visiting regularly. Transportation energy consumption and concomitant emissions in the three delivery systems (traditional networked delivery (TND) system, e-commerce networked delivery (END) system, and sustainable networked delivery (SND)) were compared. According to Kim et al. $(2008,2009)$ this new system produces fewer emissions than conventional and e-commerce delivery systems and offer meaningful economic benefit such as the costs of delivery and packaging, to the online retailer and consumer. 
In the last decade, logistics activities associated with the handling and management of products and materials to be recovered or returned to supply chain processes are termed Reverse Logistics Services (RLS). RLS have attracted considerable attention due to society's increasing concerns over resource consumption and environmental impact (Hanafi et al., 2011). In this sense, there are several works in the literature that address the use of reverse logistics in the Book Publishing sector. Wu and Cheng (2006a) explore the key factors of the reverse logistic in the Chinese Book Publishing industry based on the Analytic Hierarchy Process (AHP). Wu and Cheng (2006b) compare the characteristics of reverse logistics in the publishing industry among China, Hong Kong, and Taiwan by using a multiple-case approach in combination with EIQ (entry of order, items, and quantity) analysis. Finally, Table 1 classifies the works reviewed in terms of application area in Book Publishing sector.

\section{Discussion}

After the review process, we can observe that the majority of references deal with the calculation of the carbon footprint and environmental impacts associated with the activity of the sector. On the other hand, improvement of logistics and distribution activities is only approached by two references, while the management of materials to be recovered or returned through reverse logistics processes has been addressed by two papers. However, there is no reference which includes all actors in the supply chain Book Publishing sector or addresses globally the activities related to production, distribution, waste management and recovery of returned products, and the development of social responsibility policies focused on corporate employees, suppliers or customers. From these results, we propose several areas to be considered with the aim of improvement of the sustainability of the Book Publishing sector: (1) improvement of the competitiveness of companies involved in the Book Publishing supply chain by reducing production, distribution and operational costs; (2) improvement of the environmental performance through the optimization of materials and energy consumption along the entire supply chain and the identification of new ways for waste management and valorization through the development of a reverse logistics system; and (3) improvement of social

Table 1. Applications areas of reviewed references.

\begin{tabular}{|c|c|}
\hline Author & Application area in Book Publishing \\
\hline Green Press Initiative (2008) & Carbon footprint and environmental impacts \\
\hline Chowdhury (2010) & Carbon footprint and environmental impacts \\
\hline Matthews et al. (2008) & Carbon footprint and environmental impacts \\
\hline Matthews et al. (2002) & Carbon footprint and environmental impacts \\
\hline Williams and Tagami (2002) & Carbon footprint and environmental impacts \\
\hline Xu et al. (2008) & Carbon footprint and environmental impacts \\
\hline Xu et al. $(2009)$ & Carbon footprint and environmental impacts \\
\hline Kim et al. (2008) & Logistics and supply chain configuration \\
\hline Kim et al. (2009) & Logistics and supply chain configuration \\
\hline Wu and Cheng (2006a) & Reverse Logistics \\
\hline Wu and Cheng (2006b) & Reverse Logistics \\
\hline
\end{tabular}


performance through the improvement of worker conditions, use of raw materials from sustainable sources, networking and partnership with all the actors involved in Book Publishing Supply Chain, company's image enhancement and improvement of quality of life in general.

Some initiatives to be carried out to improve the sustainability of the Book Publishing could be: (1) analysis of the Book Publishing Supply Chain characteristics, modeling of material and information flows among the different actors and identification of improvement points for reduction of energy or material consumption and means for increasing efficiency in production or logistics; (2) creation of a reference model for sustainable forward and reverse logistics operations, which should include network configuration, supply chain and logistics planning, physical distribution and logistics assessment; and (3) identification and characterisation of environmental hot spots within the whole value chain of the book production based on carbon footprint calculations and development of a LCA tool.

\section{Conclusions}

This paper has reviewed the current status of the Sustainable Supply Chain Management concept and its application to the Book Publishing sector. The conclusions drawn from our review affirm that, in the literature, there are several works dealing with individual sustainable practices, mainly the study of environmental impacts and the calculation of carbon footprint, but no references which consider in an integrated way all partners in the supply chain Book Publishing industry (e.g. publishers, printers, distributors, retailers). Also, there are no mathematical programming and simulation models that enable production, inventory and transportation planning in the publishing sector. Besides, there are no references that address issues such as mass customization or demand driven supply chains. Thus, models are needed which consider the flow of materials, energy consumption and information throughout the supply chain and that allow economic, production and environmental managers to align their decisions with strategic, economic and social objectives of the entire supply chain.

\section{References} Vol. 34, pp. 35 .

Bey, C. (2001) Quo Vadis Industrial Ecology? Greener Management International,

Bras, B. and McIntosh, M.W. (1999) Product, process, and organizational design for remanufacture - an overview of research. Robotics and Computer-Integrated Manufacturing, Vol. 15, No. 3, pp. 167-178. http://dx.doi.org/10.1016/S0736-5845(99)00021-6

Carnegie Mellon University Green Design Initiative. (2001) Economic Input- Output Life Cycle Assessment software. Available: http://www.eiolca.net/.

Carter, C.R. and Ellram, L.M. (1998) Reverse logistics: a review of the literature and framework for future investigation. Journal of business logistics, Vol. 19, No. 1.

Carter, C.R. and Rogers, D.S. (2008) A framework of sustainable supply chain management: moving toward new theory. International Journal of Physical Distribution and Logistics Management, Vol. 38, No. 5, pp. 360-387. http://dx.doi.org/10.1108/09600030810882816

Chowdhury, G. (2010) Carbon footprint of the knowledge sector: what's the future? Journal of Documentation, Vol. 66, No. 6, pp. 934-946. http://dx.doi. org/10.1108/00220411011087878 
Council of Supply Chain Management Professionals. (2012) Supply Chain Management Definitions. Supply Chain Management Definitions. Available: http://cscmp.com/ aboutcscmp/definitions.asp.

Daily, B.F. and Huang, S. (2001) Achieving sustainability through attention to human resource factors in environmental management. International Journal of Operations and Production Management, Vol. 21, No. 12, pp. 1539-1552. http://dx.doi.org/10.1108/01443570110410892

De Boer, J. (2003) Sustainability labelling schemes: the logic of their claims and their functions for stakeholders. Business Strategy and the Environment, Vol. 12, No. 4, pp. 254-264. http://dx.doi.org/10.1002/bse.362

Dyllick, T. and Hockerts, K. (2002) Beyond the business case for corporate sustainability. Business Strategy and the Environment, Vol. 11, No. 2, pp. 130-141. http://dx.doi. org/10.1002/bse. 323

Elkington, J. (1998) Cannibals with Forks: The triple bottom line of 21st Century Business. New Society Publishers.

Elkington, J. (2004) Enter the triple bottom line. The Triple Bottom Line: Does It All Add up? London: Earthscan, pp. 1-16.

Federation of National Associations of Distributors of Editions in Spain. (2012) System of standardization documentary Sector from the book (SINLI). Available: http://www. fande.es/Sinli/sinli.asp.

Fleischmann, M.; Bloemhof-Ruwaard, J.M.; Dekker, R.; Van der Laan, E.; Van Nunen, J.A.E.E. and Van Wassenhove, L.N. (1997) Quantitative models for reverse logistics: A review. European Journal of Operational Research, Vol. 103, No. 1, pp. 1-17. http://dx.doi. org/10.1016/S0377-2217(97)00230-0

Fleischmann, M.; Beullens, P.; Bloemhof-Ruwaard, J.M. and Wassenhove, L.N. (2001) The Impact of Product Recovery on Logistics Network Design. Production and Operations Management, Vol. 10, No. 2, pp. 156-173. http://dx.doi.org/10.1111/j.1937-5956.2001.tb00076.x

Fleischmann, M.; Krikke, H.R.; Dekker, R. and Flapper, S.D.P. (2000) A characterisation of logistics networks for product recovery. Omega, Vol. 28, No. 6, pp. 653-666. http://dx.doi.org/10.1016/S0305-0483(00)00022-0

Foerstl, K.; Reuter, C.; Hartmann, E. and Blome, C. (2010) Managing supplier sustainability risks in a dynamically changing environment - Sustainable supplier management in the chemical industry. Journal of Purchasing and Supply Management, Vol. 16, No. 2, pp. 118 130. http://dx.doi.org/10.1016/j.pursup.2010.03.011

Green Press Initiative. (2008) Reducing Climate Impacts: A Guide for the Book and Newspaper Industries. Available: www.greenpressinitiative.org.

Guide Junior, V.D.R.; Jayaraman, V. and Srivastava, R. (1999) Production planning and control for remanufacturing: a state-of-the-art survey. Robotics and Computer-Integrated Manufacturing, Vol. 15, No. 3, pp. 221-230. http://dx.doi.org/10.1016/S0736-5845(99)00020-4

Guide, V.D.R.; Srivastava, R. and Kraus, M.E. (1997a) Product structure complexity and scheduling of operations in recoverable manufacturing. International Journal of Production Research, Vol. 35, No. 11, pp. 3179-3200. http://dx.doi.org/10.1080/002075497194345

Guide, V.D.R.; Srivastava, R. and Spencer, M.S. (1996) Are production systems ready for the green revolution? Production and Inventory Management Journal, Vol. 37, pp. 70-76.

Guide, V.D.R.; Srivastava, R. and Spencer, M.S. (1997b) An evaluation of capacity planning techniques in a remanufacturing environment. International Journal of Production Research, Vol. 35, No. 1, pp. 67-82. http://dx.doi.org/10.1080/002075497195984 
Gungor, A. and Gupta, S.M. (1999) Issues in environmentally conscious manufacturing and product recovery: a survey. Computers and Industrial Engineering, Vol. 36, No. 4, pp. 811-853. http://dx.doi.org/10.1016/S0360-8352(99)00167-9

Hanafi, Z.; Li, D. and Drake, P. (2011) An optimisation model for paper recycling logistics network, in: Proceedings of ICOSCM, Beijing.

Hill, M.R. (2001) Sustainability, greenhouse gas emissions and international operations management. International Journal of Operations and Production Management, Vol. 21, No. 12, pp. 1503-1520. http://dx.doi.org/10.1108/EUM0000000006292

Hoffman, A.J. (2000) Competitive environmental strategy: A guide to the changing business landscape. Island Pr.

Hui, I.; Chan, A.H. and Pun, K. (2001) A study of the Environmental Management System implementation practices. Journal of Cleaner Production, Vol. 9, No. 3, pp. 269-276. http://dx.doi.org/10.1016/S0959-6526(00)00061-5

International Organisation for Standardisation. (2012) website of the International Organisation for Standardisation. Available at: www.iso.org

Jayaraman, V.; Patterson, R.A. and Rolland, E. (2003) The design of reverse distribution networks: Models and solution procedures. European Journal of Operational Research, Vol. 150, No. 1, pp. 128-149. http://dx.doi.org/10.1016/S0377-2217(02)00497-6

Jennings, P.D. and Zandbergen, P.A. (1995) Ecologically Sustainable Organizations: An Institutional Approach. The Academy of Management Review, Vol. 20, No. 4, pp. 1015-1052.

Kim, J.; Xu, M.; Kahhat, R.; Allenby, B. and Williams, E. (2008) Design and assessment of a sustainable networked system in the U.S.; Case study of book delivery system, in: Proceedings of IEEE International Symposium on Electronics and the Environment, pp. 1-5.

Kim, J.; Xu, M.; Kahhat, R.; Allenby, B. and Williams, E. (2009) Designing and Assessing a Sustainable Networked Delivery (SND) System: Hybrid Business-to-Consumer Book Delivery Case Study. Environmental Science and Technology, Vol. 43, No. 1, pp. 181-187. http://dx.doi.org/10.1021/es800648s

Lambert, D.M. (2008) Supply chain management: processes, partnerships, performance. Supply Chain Management Inst.

Lippmann, S. (1999) Supply chain environmental management: Elements for success. Corporate Environmental Strategy, Vol. 6, No. 2, pp. 175-182. http://dx.doi.org/10.1016/S10667938(00)80027-5

Matthews, H.S.; Hendrickson, C.T. and Weber, C.L. (2008) The Importance of Carbon Footprint Estimation Boundaries. Environmental Science and Technology, Vol. 42, No. 16, pp. 5839-5842. http://dx.doi.org/10.1021/es703112w

Matthews, H.S.; Williams, E.; Tagami, T. and Hendrickson, C.T. (2002) Energy implications of online book retailing in the United States and Japan. Environmental Impact Assessment Review, Vol. 22, No. 5, pp. 493-507. http://dx.doi.org/10.1016/S01959255(02)00024-0

Mentzer, J.T.; DeWitt, W.; Keebler, J.S.; Min, S.; Nix, N.W.; Smith, C.D. and Zacharia, Z.G. (2001) Defining Supply Chain Management. Journal of Business Logistics, Vol. 22, No. 2, pp. 1-25. http://dx.doi.org/10.1002/j.2158-1592.2001.tb00001.x

Min, H. and Galle, W.P. (1997) Green Purchasing Strategies: Trends and Implications. Journal of Supply Chain Management, Vol. 33, No. 3, pp. 10-17. http://dx.doi.org/10.1111/j.1745493X.1997.tb00026.x

Olugu, E.U.; Wong, K.Y. and Shaharoun, A.M. (2010) A Comprehensive Approach in Assessing the Performance of an Automobile Closed-Loop Supply Chain. Sustainability, Vol. 2, No. 4, pp. 871-889. http://dx.doi.org/10.3390/su2040871 
Peattie, K. (1995) Environmental marketing management: meeting the green challenge. Financial Times Management.

Pihkola, H.; Nors, M.; Kujanpää, M.; Helin, T.; Kariniemi, M.; Pajula, T.; Dahlbo, H. and Koskela, S. (2010) Carbon footprint and environmental impacts of print products from cradle to grave. Results from the LEADER project (part 1). Available: http://www.vtt.fi/inf/pdf/ tiedotteet/2010/T,2560.

Reinhardt, F.L. (1999) Bringing the environment down to earth. Harvard Business Review, Vol. 77, No. 4, pp. 149-157, 186.

Rotz, C.A.; Montes, F. and Chianese, D.S. (2010) The carbon footprint of dairy production systems through partial life cycle assessment. Journal of Dairy Science, Vol. 93, No. 3, pp. 1266-1282. http://dx.doi.org/10.3168/jds.2009-2162

Sadegheih, A.; Li, D.; Sribenjachot, S. and Drake, P.R. (2010) Applying mixed integer programming for green supply chain management: general article. South African Journal of Industrial Engineering, Vol. 21, No. 2, pp. 13-24.

Sarkis, J. (2001) Manufacturing's role in corporate environmental sustainability - Concerns for the new millennium. International Journal of Operations and Production Management, Vol. 21, No. 5-6, pp. 666-686. http://dx.doi.org/10.1108/01443570110390390

Sarkis, J. and Cordeiro, J.J. (2001) An empirical evaluation of environmental efficiencies and firm performance: Pollution prevention versus end-of-pipe practice. European Journal of Operational Research, Vol. 135, No. 1, pp. 102-113. http://dx.doi.org/10.1016/S03772217(00)00306-4

Seuring, S. and Müller, M. (2008) From a literature review to a conceptual framework for sustainable supply chain management. Journal of Cleaner Production, Vol. 16, No. 15, pp. 1699-1710. http://dx.doi.org/10.1016/j.jclepro.2008.04.020

Sheth, J. and Parvatiyar, A. (1995) Ecological imperatives and the role of marketing. In: Polonsky, M.J. and Mintu-Wimsatt, A. Environmental Market-ing: Strategies, Practice, Theory, and Research. New York: The HaworthPress, pp. 3-20.

Shrivastava, P. (1995) The Role of Corporations in Achieving Ecological Sustainability. The Academy of Management Review, Vol. 20, No. 4, pp. 936-960. http://dx.doi. org/10.1111/j.1468-2370.2007.00202.x

Spanish Association of Publishers Guilds. (2012) Programme for the improvement of processes as part of the supply chain, books: (CSL standards). Available: http://www. federacioneditores.org/Convocatorias/Folleto_CSL.pdf.

Spanish Confederation of Booksellers' Associations. (2012) Databases of books for sale (DILVE and CEGAL network). Available: http://www.cegal.es/lib/informes/introInformes. php?codTipoInformeAsoPrincipal=20.

Srivastava, S.K. (2007) Green supply-chain management: A state-of-the-art literature review. International Journal of Management Reviews, Vol. 9, No. 1, pp. 53-80.

Starik, M. and Rands, G.P. (1995) Weaving an Integrated Web: Multilevel and Multisystem Perspectives of Ecologically Sustainable Organizations. The Academy of Management Review, Vol. 20, No. 4, pp. 908-935.

Stivers, R.L. (1976) The sustainable society: ethics and economic growth. Westminister Press.

Svensson, G. (2007) Aspects of sustainable supply chain management (SSCM): conceptual framework and empirical example. Supply Chain Management: An International Journal, Vol. 12, No. 4, pp. 262-266. http://dx.doi.org/10.1108/13598540710759781

Vol. 1.

Welford, R. (1999) Life cycle assessment. Corporate environmental management, 
Williams, E. and Tagami, T. (2002) Energy Use in Sales and Distribution via E-Commerce and Conventional Retail: A Case Study of the Japanese Book Sector. Journal of Industrial Ecology, Vol. 6, No. 2, pp. 99-114. http://dx.doi.org/10.1162/108819802763471816

World Commission on Environment and Development. (1987) Our common future. Oxford: Oxford University Press.

Wu, Y.-C.J. and Cheng, W.-P. (2006a) Reverse Logistics of China's Publishing Industry- AHP Analysis, in: Proceedings of IEEE International Conference on Service Operations and Logistics, and Informatics, pp. 499-504. http://dx.doi.org/10.1109/SOLI.2006.328937

Wu, Y.-C.J. and Cheng, W.-P. (2006b) Reverse logistics in the publishing industry: China, Hong Kong, and Taiwan. International Journal of Physical Distribution and Logistics Management, Vol. 36, No. 7, pp. 507-523. http://dx.doi.org/10.1108/09600030610684953

$\mathrm{Wu}, \mathrm{Z}$. and Pagell, M. (2011) Balancing priorities: Decision-making in sustainable supply chain management. Journal of Operations Management, Vol. 29, No. 6, pp. 577-590. http://dx.doi.org/10.1016/j.jom.2010.10.001

Xu, M.; Allenby, B.; Kim, J. and Kahhat, R. (2009) A Dynamic Agent-Based Analysis for the Environmental Impacts of Conventional and Novel Book Retailing. Environmental Science \& Technology, Vol. 43, No. 8, pp. 2851-2857. http://dx.doi.org/10.1021/es802219m

$\mathrm{Xu}$, M.; Kim, J.; Kahhat, R. and Allenby, B. (2008) Market dynamics and environmental impacts of e-commerce: A case study on book retailing, in: Proceedings of IEEE International Symposium on Electronics and the Environment, pp. 1-6.

Young, A. and Kielkiewicz-Young, A. (2001) Sustainable Supply Network Management. Corporate Environmental Strategy, Vol. 8, No. 3, pp. 260-268. http://dx.doi. org/10.1016/S1066-7938(01)00122-1

Zhang, H. C.; Kuo, T. C.; Lu, H. and Huang, S. H. (1997) Environmentally conscious design and manufacturing: A state-of-the-art survey. Journal of Manufacturing Systems, Vol. 16, No. 5, pp. 352-371. http://dx.doi.org/10.1016/S0278-6125(97)88465-8

Zhu, Q. and Geng, Y. (2001) Integrating Environmental Issues into Supplier Selection and Management. Greener Management International, Vol. 35, pp. 27.

Zhu, Q. and Sarkis, J. (2004) Relationships between operational practices and performance among early adopters of green supply chain management practices in Chinese manufacturing enterprises. Journal of Operations Management, Vol. 22, No. 3, pp. 265-289. http://dx.doi.org/10.1016/j.jom.2004.01.005

Zikmund, W.G. and Stanton, W.J. (1971) Recycling solid wastes: a channels-ofdistribution problem. The Journal of Marketing, pp. 34-39. http://dx.doi.org/10.2307/1249787

Zsidisin, G.A. and Siferd, S.P. (2001) Environmental purchasing: a framework for theory development. European Journal of Purchasing and Supply Management, Vol. 7, No. 1, pp. 61-73. http://dx.doi.org/10.1016/S0969-7012(00)00007-1

\section{Biography}

Manuel Díaz-Madroñero is Teaching Assistant in the Department of Business Management and researcher at the Research Centre on Production Management and Engineering (CIGIP) at the Universitat Politècnica de València (Spain). He is Master Degree in Advanced Production Engineering, Logistics and Supply Chain at the Universitat Politècnica de València in 2009. Mr. Díaz-Madroñero is currently doing his $\mathrm{PhD}$ dissertation on the integration of transport planning and MRP systems and extensions. His research interests are oriented to production planning, transport planning, supply chain management and mathematical programming models under uncertainty.

Contact: fcodiama@cigip.upv.es 
Dr. Josefa Mula is a Senior Lecturer in operations management at the Universitat Politècnica de València. She is member of the scientific committee of the Research Centre on Production Management and Engineering (CIGIP) in which she has developed R\&D Projects in the areas of industrial management and supply chain management. Her key research topics include production planning and control, supply chain management and uncertainty modelling. She has published (in collaboration) more than forty research papers in a number of leading journals. She has written (in collaboration) the book Supply Chain Simulation: A system dynamics approach for improving performance. She is Editor of the Journal of Industrial Engineering and Management and member of the Editorial Board of the Journal of Industrial Engineering.

Contact: fmula@cigip.upv.es

Dr. Raúl Poler is Professor in Operations Management and Operations Research at the Universitat Politècnica de València (UPV). He received his $\mathrm{PhD}$ in Industrial Engineering from UPV in 1998. He is Director of the Research Centre on Production Management and Engineering (CIGIP). He has lead several European research projects. He has published a hundred of research papers in a number of leading journals and in several international conferences. He is the Representative of INTERVAL (the Spanish Pole of the INTEROP-VLab). He is member of several research groups and associations as IFIP WG 5.8 Enterprise Interoperability, EurOMA, POMS, and ADINGOR among other. His key research topics include Enterprise Modelling, Knowledge Management, Production Planning and Control and Supply Chain Management.

Contact: rpoler@cigip.upv.es

\section{Article Info:}

Received: August, 2012

Accepted: October, 2012 